\title{
The Methodological and Didactic Aspects of Comprehensive Greening of Educational Process Towards Sustainable University
}

\author{
Yuriy Tunytsya ${ }^{1,}{ }^{*}$, Ihor Soloviy ${ }^{2}$, Vasyl Lavnyy ${ }^{3}$ \\ ${ }^{1,2,3}$ Ukrainian National Forestry University, Generala Chuprynky, 103, Lviv, Ukraine \\ * corresponding author: rector@nltu.edu.ua
}

\section{Article Info}

Received:

15 March 2021

Accepted:

25 May 2021

Published:

1 August 2021

DOI:

Presented in The $6^{\text {th }}$ International (Virtual) Workshop on UI GreenMetric World University Rankings (IWGM 2020)

\begin{abstract}
The process of greening education is aimed to educate new generation with the holistic vision of the real world challenges, attitudes of responsibility and active social behavior as an agent of sustainability transformations. The methodological and didactic aspects of comprehensive greening of educational process discussed. It's based on integration the competence and the whole school approaches, sustainable life style and green campus practices into sustainable university model. The preconditions for systemic and holistic integration of the sustainability principles into all fields of the university life are identified. Especial attention is paid to the recent experiences of the Ukrainian National Forestry University as the leading university in Ukraine in implementing the concept of greening higher education in Ukraine and member of new networking project "V4 Green Universities" supported by the Visegrad Fund.
\end{abstract}

\section{Keyword:}

education for sustainable development, greening of education, competence approach, sustainable university model.

\section{Introduction}

The concept of sustainable development is a common agenda for addressing the global challenges to the society in the $21^{\text {st }}$ century, which requires a paradigm shift for the human development trajectories. It's require responsible attitude to the environment and natural resources, economic development, education, and culture. But bringing this global concern into public policies is a difficult task. We need to accept that we now live in a full world context where natural and social capital are the limiting factors. We could achieve a much higher quality of life, and one that would be ecologically sustainable, socially fair, and economically efficient, if we shift to a new sustainable development paradigm that incorporates these principles [1].

Education is recognized as the most effective tool for implementing the strategy of sustainable development. Inclusive and quality education and lifelong learning incentives 
are among the highest priorities of the 2030 Agenda for Sustainable Development, adopted at the UN Development Summit (2015), and the Education 2030 Framework for Action, the foundation that anchor global efforts to achieve Sustainable Development Goal 4 (SDG 4). In the light of these global trends the education system, its transformation on the basis of sustainable development is becoming relevant as a scientific, methodological, organizational and managerial problem.

The dominant technocratic paradigm of education treats the abilities of future professional activities because of simplified studying instead of learning or getting the most relevant competences by future professionals, which ultimately led to a huge gap between technical, instrumental decision-making ability and a comprehensive understanding of their consequences. Therefore, education should provide the graduates not only with knowledge based on the philosophical and historical contexts, but also to initiate the formation of new norms of responsible professional and everyday behavior, holistic worldview and development vision. There must be a rethinking of social and personal values to understand that the quality of environment is a fundamental component of everyone's well-being that is necessary for man as a biological being, the prosperity of life on Earth and its diversity.

\section{Methodology and Results}

\subsection{Methodological approach}

The ongoing research is aimed at implementing the commitments made at the UN Summit "Rio + 20" on behalf of Ukraine entitled: "Greening of Education: Ukraine's Contribution" [7].

The study of worldview and methodological aspects of the education for sustainable development process was based on the achievements of didactics as a theory of learning. This aspect of the issue reflected the specific feature the process of greening of the specialists training in various professional fields: in the field of natural resource management and environmental protection, technical, economic, socio-humanitarian, arts and more. The latest system-synergetic methodology of scientific knowledge was used to

solve the research problems, which allowed to present the basic concepts necessary for modeling man, nature, economy, and society interrelations from the standpoint of sustainable development paradigm as an integrated object of scientific and educational activities.

Post-classical science, which studies systems using interdisciplinary synergetic approaches, serves as a methodological basis that allows to rise to a higher level in the study of evolving systems, overcoming the limitations of technocratic science and education [6]. Therefore, in education for sustainable development, the theory of complex systems and system dynamics are considered as important disciplines.

\subsection{The concept of the comprehensive greening of educational process}

An important notable trend in the development of the education system today is the greening of education, in particular the process of education for sustainable development. Greening of education is understood as a process of saturation of study programs in all fields with environmental aspects in order to form an ecological-economic thinking instead of one-sided traditional economic thinking. Then an education for sustainable development is seen as expanding the process of greening of education, holistic understanding of the interdependence and interdependence of economic, environmental and social systems. 
The Ukrainian National Forestry University (UNFU) initiated and gained significant experience in development programs for greening the curricula in various specialties, the introduction of new modern master's programs for training specialists in environmentally friendly and resource-saving technologies, environmental economics and natural resources, as well as conducting systematic research, educational and educational activities, aimed at the formation of environmental awareness and ecological culture of students [5/6/9].

The UNFU together with the National Technical University of Ukraine "Kyiv Polytechnic Institute" initiated the discussion of the issue of greening of national education at the level of the Board of the Ministry of Education and Science of Ukraine. Based on its results, the Decision of November 27, 2015 "On greening higher education of Ukraine in order to train specialists for sustainable development" [3]. This document identifies the experience gained in the implementation of greening of education concept for the purpose of training the specialists for sustainable development, which can serve as the basis for reforming the education system at the national level.

Introduction on the initiative of the UNFU on including "ecological competence" to state standards of education - from primary to higher school, became an important stage in solving one of the educational problems - ensuring the practical implementation of the triad "environmental upbringing - environmental study - environmental education". Every component of this triad is interconnected with others and contributing to formation of a person's ecological worldview, based on the awareness of the need to preserve the optimal environment for securing the life on the planet.

Greening of education is the main prerequisite for the transition to greening the economy (saturation of environmental requirements of production and consumption patterns in order to prevent or mitigate their negative impact on the environment), green economy (environmentally safe and resource-efficient way of management), achieving sustainable development goals and the formation of a new society (with ecologicaleconomic worldview and sustainable resource management).

\subsection{The recent experiences of the greening study programs at the UNFU}

The worldview and general methodological preconditions for greening universities' educational activity on the basis of the concept of human capital for sustainable development foresee that the aim of greening educational activity is to educate new generation with holistic vision of the real world, essential feeling of responsibility and active social behaviour as a pioneer of sustainability transformations. The functional model of sustainable development civilization harmoniously combines the political-legal, economic and ecological subsystems [9].

The role of the whole school approach in shaping the modern educational discourse for sustainable development is substantiated. This approach determines efficiency of education, induces changes in professional and everyday behaviour. The preconditions for systemic and holistic integration of the sustainability principles into all spheres of a university activity are determined. To understand the essence of sustainable development is necessary diverse competence based on readiness to think, act and take responsibility based on a holistic understanding of the preconditions for sustaining life on Earth in a global perspective. It encompasses a willingness to constantly learn from others and collaborate, overcoming disciplinary and professional constraints, thinking, critically analyzing and solving problems, looking for opportunities and overcoming limitations in professional 
functions. The ability to think comprehensively and involve the experts from different fields is crucial. The leaders need to be enthusiastic and think creatively.

The redesigning of curricula based on the Concept of Greening of Education is achieved at the UNFU through such main steps:

1. Developing of the study programs fully aimed at training of new types of experts - so called "specialist-generalists" responsible for designing strategies of sustainable development at different levels of territorial and sectoral levels (ENARECO - Environment and Natural Resource Economics MSc Program developed in the framework of EU Tempus-Tacis Program in 1997-2001 and still successfully functioning);

2. Comprehensive greening of all courses which are taught of the University (with it discussion at the level of Methodological Boards of the university institutes);

3. Teaching of courses (obligatory and elective depending from program) for students of different programs which propose the sustainability based worldview (Ecological Economics, Sustainable Development, and Philosophy of Sustainable Development).

4. Teaching of courses (obligatory and elective depending from program) for students of different programs which propose the instrumental knowledge and skills for solving environmental problems and designing sustainability decisions (Methodologies of Environmental Economics, Environmental Policy, Sustainable Bioenergy, Applied Environmental Marketing, Environmental Management, etc.).

5. Practical skills for solving environmental problems and designing sustainability decisions (different internships, participation in reaserch projects).

The results of the study modification testified the effectiveness of the strategy of greening the educational process, introduced at the UNFU. Regardless of the profile of the specialty, students develop a careful attitude to nature, understanding of its living essence and the need to adhere to the norms of environmentally-oriented behavior. At the same time, the level of students' awareness of the urgency of environmental problems depends on the specifics of their training (how their future professional activity is included in the system "man - nature"): the highest maturity of environmental awareness was found for students of the MSc Program "Environment and Natural Resource Economics".

\subsection{Close to Nature Forestry approach: case of eco-innovation in theory and on practice}

The motto of the UNFU "Learning to live in a harmony with nature" is actively implemented in practice during the training students of all bachelors and masters programs but each program has different valuable experience. For example, the students of the Forestry Program (BSc, MSc) learn how to apply the theoretical and practical principles of the close to nature forestry.

Close to nature forestry is aimed at maximum use of natural processes of growth, development and interaction of tree species in order to form mixed, different ages, highly productive, healthy and economically valuable forest stands with minimal financial costs. The theory of such kind of forestry is based on the following principles:

1. Formation of mixed and different age stands. This reduces the possible climate change risks in the future or the economic situation at the market (periodic fluctuations in wood prices of different species).

2. Increasing the biological stability of stands due to the formation of well-developed crowns from a young age and removal during the next reception of felling of diseased or damaged trees.

3. Use of local (autochthonous) wood species in accordance with existing forest types. 
4. Ensuring constant natural regeneration of tree species in forest stands.

5. Refusal of clear cut felling. Instead, a selective forest management system should be used.

6. Growing and selling large wood assortments of high quality.

7. Maintaining the natural fertility of soils without mineral fertilizers.

8. The use of environmentally friendly methods of logging through the use of modern conservation machines and technologies.

9. Ensuring the biodiversity of flora and fauna by preserving rare habitats and leaving dead wood in forests.

10. The use of the process of natural selection and differentiation of trees during the removal of trees for intermediate felling.

11. The formation of a diverse vertical and horizontal structure of the stand, i.e. the growth of trees of different species and different diameters and heights.

Primeval forests of the Ukrainian Carpathians are a valuable natural model for close to nature forestry. Observations of the natural processes of virgin forest development allow to obtain useful guidelines for forest management in commercial forests. That is why foresterspractitioners and students from Germany, Switzerland and other European countries come here every year for field studies and internships. Foresters from many countries, while getting acquainted with the virgin forests of the Ukrainian Carpathians are getting inspiration and encouragement to conduct close-to-nature forestry in their state, municipal or private forests. Moreover, they also invite new students and interns to study this treasure of nature.

In recent years, the interest of well-known international research institutions in joint research of virgin forests in the Ukrainian Carpathians has been growing. An example of such scientific cooperation is the implementation of the Swiss-Ukrainian scientific project on "Statistical inventory of the Uholka-Shyrokoluzhanskyy beech virgin forest", which was carried out in 2009-2010 and repeatedly in 2019 [2]. Until now, in the virgin forests of Europe, studies of their structure and structure have been conducted only on small test plots. A systematic inventory of such a large area of beech virgin land has never been carried out in Europe.

Close to nature, multi-purpose forestry approach is implemented in Stradch Training and Production Forestry Enterprise and in the state enterprise "Lviv Forestry" in the framework of a Joint research and development project "Transformation of pine forests to a close-to nature forest management in Ukraine and with special consideration of resilience to fire and climate extremes such as drought", (Scientific supervisor of the project - Prof. Vasyl Lavnyy) which is carried out jointly with the University of Sustainable Development Eberswalde (Germany).

The model enterprise in the project is the State Enterprise "Lviv Forestry". This enterprise does not use clear-cut felling, but only a selective forestry system. Due to this, there are no clear cut areas in its forests, preference is given to natural regeneration of forests. In addition, foresters leave to grow individual micro-settlements trees in each area, which are marked on the trunk with the letter "E" (for environmental needs). The company's management has established a mutually beneficial dialogue with environmental organizations and local communities, so there are no conflicts during forest management.

Close to nature forestry approach is an example of eco-innovation of guiding activities in a manner which is responsible for preserving the environment. It helps to improve the protective functions of the forest, including the protection of water resources and the 
reduction of soil erosion. In addition, this form of forestry improves the aesthetic value of forest areas, which is important in modern conditions to increase the demand of urban residents for recreation in forests.

\subsection{International collaboration on developing greening of education methodologies}

The V4 Green Universities (V4GU) project (01/03/2020 - 31/08/2021) is co-financed by the Governments of Czech Republic, Hungary, Poland and Slovakia through Visegrad Grants from International Visegrad Fund. Duration: The mission of the fund is to advance ideas for sustainable regional cooperation in Central Europe.bV4GU projects targets the younger generation, who are the most susceptible. Universities represent large communities with their thousands of employees and ten thousands of students, who can also act as multipliers by sharing their eco-conscious practices with friends, family, wider public via social media. Universities are also equipped with the scientific knowledge to measure the climate impacts of people's everyday routines, identify reduction potentials, measure results. The partners are engaged member universities of the worldwide network of UI GreenMetric World University Ranking [https://greenmetric.ui.ac.id], which calls the attention of university leaders and stakeholders on global climate change, the importance of energy and water conservation, waste recycling, and green transportation.

Together with University of Pécs, consortium leader of V4GU, the following partners take part in the implementation Czech University of Life Sciences Prague (Česká zemědělská univerzita v Praze), Czech Republic, The Slovak University of Agriculture in Nitra (Slovenská pol'nohospodárska univerzita $v$ Nitre), Slovakia, University of Kragujevac (Универзитет у Крагујевцу), Serbia, Ukrainian National Forestry University (Державний вищий навчальний заклад «Національний лісотехнічний університет України), Ukraine. The project builds the awareness raising campaign and knowledge exchange on the following activities: V4 Green University conferences and local (national) workshops, organizing video campaigns and social competitions for students. We focus in identifying what tools touch the students [8]. The diversity of activities and exchange of ideas allow to involve universities for mobilizing students, lecturers and employees to change their behavior and integrate eco-conscious routines into their everyday practices like food consumption, travel or use of water. The aim is to explain the students how their everyday habits influence the climate and how their behavior could be transformed to an eco-conscious attitude. Partners will organize social competitions in each country to activate their students, and incite them for changing their behavior.

\section{Summary/ Concluding Remarks}

To achieve the goals of sustainable development, universities must abandon the narrow specialization in science and training of specialists with higher education. A specialist for sustainable development, regardless of what specialty he acquired as a result of higher education - it must be a specialist with established environmental competence, i.e. the ability to interact harmoniously with the environment and society in all spheres of life. Substantiating the need to consider the environmental competence of a specialist with higher education as an important component of his professional competence, we believe that in the list of general competencies recommended by the Ministry of Education of Ukraine of Ukraine, which are taken into account when developing new standards of higher education, this competence should be a priority. 
The requirement of time is that educational institutions not only meet the demands of modernity, but also become dynamic institutions, a kind of "laboratories of social ecoinnovation", which is always one step ahead of any social change. That is why many countries have integrated sustainability principles into national development strategies over the past two decades. These influences have not escaped the strategy of educational development [4]. On the other hand, the transition to the principles of sustainable development is largely due to changes in the system of education and training of professionals with new qualifications (so-called green skills).

The modern university is a social institution in which human capital of the highest quality accumulates. In order to fulfill this high social purpose, it must acquire a new quality to overcome crisis phenomena in its functioning and ensure the realistic visioning for sustainable development.

\section{References}

1. Costanza, R. Ecological economics: creating a sustainable and desirable future. Ecological economics and sustainable forest management: developing a transdisciplinary approach for the Carpathian Mountains. Edited by I.P. Soloviy, W.S. Keeton. - Lviv: Ukrainian National Forestry University Press, Liga-Pres, 2009. - pp 37.

2. Commarmot, B., Brändli, U.-B., Hamor, F., Lavnyy, V. 2013. Inventory of the Largest Primeval Beech Forest in Europe. A Swiss-Ukrainian Scientific Adventure. - Birmensdorf, Swiss Federal Research Institute WSL; Lviv, Ukrainian National Forestry University; Rakhiv, Carpathian Biosphere Reserve, 2013. - 69 p.

3. Decision of the Collegium of the Ministry of Education of Ukraine, 2015. On greening of higher education aimed on training of specialists for sustainable development. From 27.11.2015 p. Retrieved from: http://mon.gov.ua/content/Новини/2015/12/30/10-54.zip. [In Ukrainian].

4. Soloviy, I. P., Henyk, Ya. V., \& Soloviy, V. I. , 2014. Managent of the professional educational institution on the basis of sustainable development. - Ivano-Frankivsk: LileiaNV, 162 p. [In Ukrainian].

5. Tunytsya, Yu. Yu., Lysko, L. R., Zahvoyska, L. D., \& Soloviy, I. P. , 2019. Sustainable university: the model of systemic integration of sustainability priciples in all spheres of activity. Scientific Bulletin of UNFU, 29(10), 54-60. https://doi.org/10.36930/40291010

6. Tunytsya, Yu. Yu., Zahvoiska, L. D., \& Adamovskyi, O. M. (2016). Economic discourse of education for sustainable development. Higher School, 4 (74), 7-27. Retrieved from: http://ieem.nltu.edu.ua/images/docs/2016_vyshchaschool.pdf. [In Ukrainian].

7. UN, 2012. Greening of Education: Ukraines Contribution. Retrieved from: https://sustainabledevelopment.un.org/partnership/?p=77

8. V4 Green Universities (V4GU). - Retrieved from: https://zoldegyetem.pte.hu/en/v4gu

9. Tunytsya, Yu. Yu., Adamovskyi, M. H., Borys, M. M., Kraievskyi, S. N., \& Mahazynshchykova, I. P., 2015. Greening of education as a key factor for training specialists for sustainable development. Scientific Bulletin of UNFU, 25(10), 348-356. https://doi.org/10.15421/40251053 